\title{
Response of epilithic microphytobenthos of the Western Baltic Sea to in situ experiments with nutrient enrichment
}

\author{
H. Hillebrand*, U. Sommer \\ Abt. Meeresbotanik, Institut für Meereskunde, Düsternbrooker Weg 20, D-24105 Kiel, Germany
}

\begin{abstract}
The response of epilithic microphytobenthos to in situ nutrient enrichments was studied in the Kiel Fjord, Western Baltic Sea. For this purpose an experimental setup with continuous nutrient supply was designed and installed. Experiments followed the colonization of artificial substrates and the responses of benthic algae to different concentrations and combinations of nitrogen and phosphate. They revealed nitrogen limitation of epilithic microflora from late spring to autumn, such that there was higher biovolume with increasing nitrogen concentrations. Diatoms became dominant in all experiments except one in which the rhodophyte Ceramium strictum prevailed. Species composition was altered by nutrient treatments; one to several species were highly favoured by nutrient enrichment. Consequently, diversity was negatively correlated with final yield. These findings support the hypothesis that competition is an important factor structuring microphytobenthic communities.
\end{abstract}

KEY WORDS: Competition - Nitrogen - Phosphate - Microphytobenthos - Diatoms - Filamentous algae Periphyton - Kiel Fjord

\section{INTRODUCTION}

Benthic microalgae play an important role in littoral production (Cadée 1980, Daehnick et al. 1992), but studies dealing with benthic algal ecology are rare compared to those done on phytoplankton. During the Dutch Ems-Dollart project the response of benthic diatoms to several abiotic stress parameters, including temperature, desiccation, high sulfide and ammonia concentrations, anoxia, and high light intensities, was tested (Admiraal 1984 and references therein). The investigations revealed that these organisms have high levels of tolerance, which correspond to their harsh tidal environment. Generally, biotic interactions have been thought to be less important, so even fewer studies have taken competition or grazing into account.

Nutrient enrichment, however, has been shown to stimulate microphytobenthic biomass (Sundbäck \& Snoeijs 1991, Pinckney et al. 1995), with distinct differences in the responses of different higher taxa. To date, experimental analysis of different nutrient

·E-mail: hhillebrand@ifm.uni-kiel.de regimes has been done primarily in freshwater sites, using nutrient-diffusing agar-plates (Pringle \& Bowers 1984, Pringle 1987, 1990) or agar-filled clay pots (Fairchild et al. 1985). However, the nutrient supply via diffusion out of these substrata decreases exponentially with time, which is not optimal for competition experiments (Tilman 1982, Fairchild et al. 1985, Sommer 1996). In plankton research, continuous or semicontinuous culture techniques with constant nutrient supply rates have been successfully used for competition experiments (e.g. Tilman 1977, Sommer 1985, 1994). Therefore, we designed an in situ experimental setup in which a continuous supply of nutrients was dispensed through an artificial stone substrate. We used it to identify the yield-limiting nutrient and to study the influence of changes in the nutrient supply on the taxonomic outcome of competition.

\section{MATERIAL AND METHODS}

Experimental setup. Two types of in situ experiments, colonization and enrichment, were conducted in the Kiel Fjord, Western Baltic Sea (Fig. 1). Darkened 101 


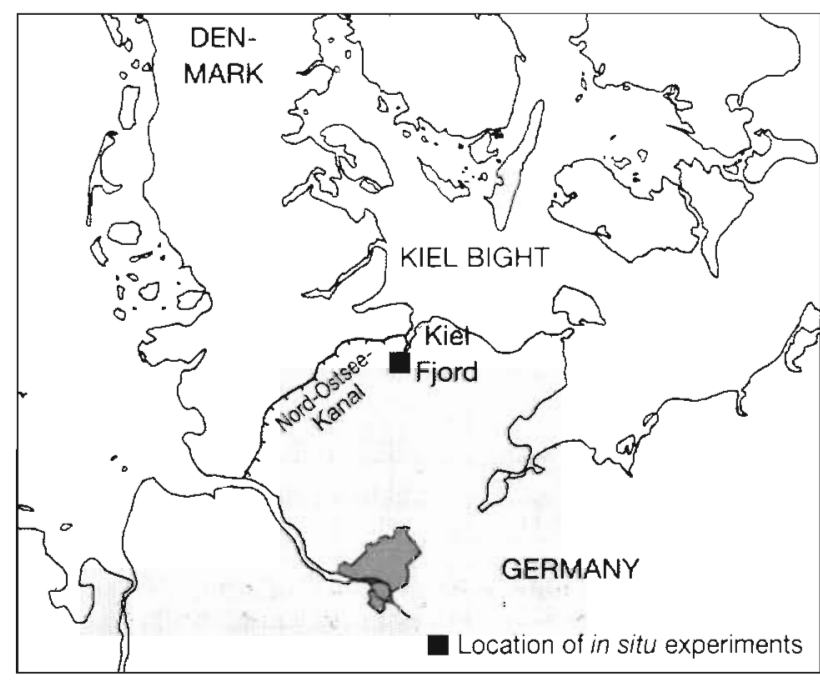

Fig. 1. Map of Western Baltic region showing experimental area

bottles were installed on top of the pier of the Institute of Marine Science in Kiel, Germany (Fig. 2) and filled with media. The media were made from seawater taken near the pier. Seawater was filtered $(0.2 \mu \mathrm{m}$ cellulose acetate filters) and enriched with different concentrations of nitrogen (as $\mathrm{NaNO}_{3}$ ) or phosphate (as $\mathrm{KH}_{2} \mathrm{PO}_{4}$ ) (Tables 1 \& 2). Concentrations of the other nutrients were not changed (cf. Fig. 7). This liquid media flowed through silicon tubes (inner diameter 4 $\mathrm{mm}$ ) and trickled out through an artificial substrate consisting of a porous stone (aquarium air stone; $50 \times$ $25 \times 25 \mathrm{~mm}$; material: infusorial earth, kieselguhr). With a precise mechanical regulation device, designed for intravenous infusion (Angiokard AK 5505), the flow rate was adjusted to $1( \pm 0.1)$ I $\mathrm{d}^{-1}$. Twice per week the supply bottle was refilled, and the flow rate was measured and readjusted if necessary.

The harvesting of substrates was performed differently for the 2 types of experiments. In the colonization experiments, all 12 treatments received the same nutrient concentrations (Table 1). By sampling 1 stone per week, we were able to follow the colonization process. Each sampled stone was replaced by a new one and at the end of the experiment all treatments were harvested again. In this way 2 series of samples were obtained. In the first series, the different incubation times had the same starting points but different harvesting points. In the second series (replacement stones) the starting points were different, but the harvesting points the same.

In the enrichment experiments, incubation times were equal between all 13 different stones of one experiment. The different treatments received different nutrient concentrations (Table 2); all substrates were sampled once at the end of the experiment. The duration of the experiments was fixed according to earlier observations of the seasonal differences in the duration of colonization. In preliminary experiments, a maximum in total biovolume was established after 5 wk in summer and $9 \mathrm{wk}$ in winter. The treatments were arranged in a gradient of nutrient supply rates rather than replicating single treatments.

Immediately after collecting, the biomass was scraped off until no pigment colour could be detected on the stones. The biomass was suspended in organism-free filtered seawater $(0.2 \mu \mathrm{m}$ cellulose acetate filters). Subsamples were taken for counting (fixed with Lugol's iodine: $10 \mathrm{~g} \mathrm{KI}+5 \mathrm{~g}$ I per $100 \mathrm{ml}$ ), determination of particulate carbon, nitrogen and phosphate (filtered on Whatman $\mathrm{GF} / \mathrm{C}$ filters; filters for $\mathrm{CN}$-analysis were heated to $545^{\circ} \mathrm{C}$ before use), and for taxonomic identification. Samples from the surrounding water of the pier were taken by making a simple scoop at surface water levels; the samples were frozen for nutrient analysis or fixed for counting.

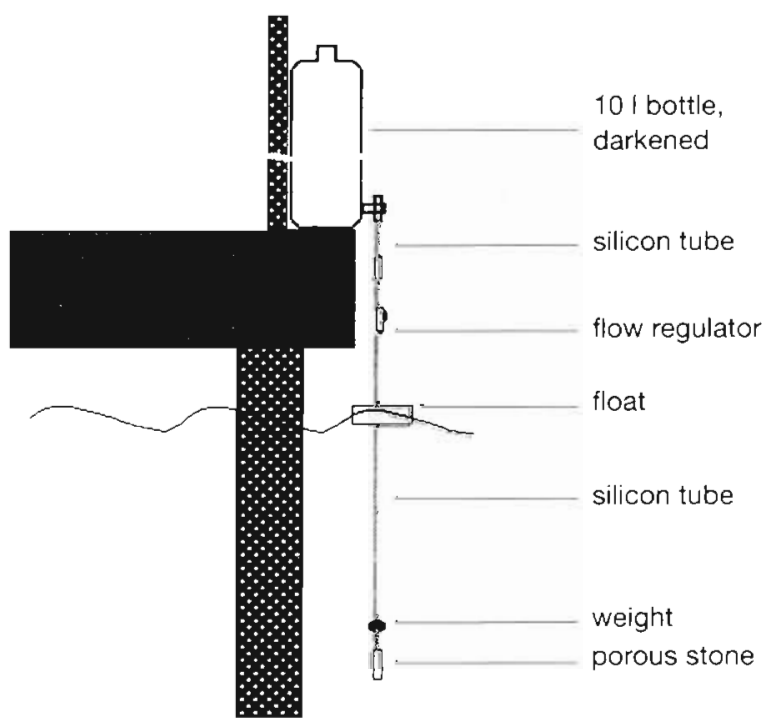

Fig. 2. Scheme of one experimental setup installed at the pier of the Institute of Marine Science, Kiel

Table 1 Treatments of colonization experiments conducted in the Kiel Fjord, listing experiment name, exact duration with date and in days (d); nutrients ( $\mathrm{N}$ and $\mathrm{P}$ ) are given in $\mu \mathrm{mol} \mathrm{l}^{-1}$

\begin{tabular}{|lccccr|}
\hline Experiment & Duration & $d$ & N & P \\
\hline Autumn 96 series 1/2 & 26 Sep-12 Dec 1996 & 77 & 150 & 10 \\
Spring 97 series 3/4 & 11 Feb-6 May 1997 & 84 & 150 & 0 \\
\hline
\end{tabular}


Table 2. Treatments of enrichment experiments in the Kiel Fjord, listing experiment name, exact duration with date and in days (d). Numbers 1 to 13 denote the different treatments; nutrient concentrations (n) are given in $\mu$ mol $1^{-1}$ The Excl. (excluded) column lists treatments not taken into account.

\begin{tabular}{|c|c|c|c|c|c|c|c|c|c|c|c|c|c|c|c|c|c|}
\hline Experiment & Duration & $\mathrm{d}$ & $\mathrm{n}$ & 1 & 2 & 3 & 4 & 5 & 6 & 7 & 8 & 9 & 10 & 11 & 12 & 13 & $\mathrm{Excl}$ \\
\hline $\begin{array}{l}\text { Spring } \\
96\end{array}$ & $\begin{array}{l}30 \mathrm{Apr}-19 \mathrm{Jun} \\
1996\end{array}$ & 50 & $\begin{array}{l}N \\
P\end{array}$ & $\begin{array}{l}0 \\
0\end{array}$ & $\begin{array}{r}15 \\
0\end{array}$ & $\begin{array}{r}45 \\
0\end{array}$ & $\begin{array}{r}150 \\
0\end{array}$ & $\begin{array}{r}450 \\
0\end{array}$ & $\begin{array}{l}0 \\
1\end{array}$ & $\begin{array}{l}0 \\
3\end{array}$ & $\begin{array}{r}0 \\
10\end{array}$ & $\begin{array}{r}0 \\
30\end{array}$ & $\begin{array}{r}15 \\
1\end{array}$ & $\begin{array}{r}45 \\
3\end{array}$ & $\begin{array}{r}150 \\
10\end{array}$ & $\begin{array}{r}450 \\
30\end{array}$ & 4 \\
\hline $\begin{array}{l}\text { Late summer } \\
96\end{array}$ & $\begin{array}{l}13 \text { Aug-23 Sep } \\
1996\end{array}$ & 41 & $\begin{array}{l}\mathrm{N} \\
\mathrm{P}\end{array}$ & $\begin{array}{l}0 \\
0\end{array}$ & $\begin{array}{r}15 \\
0\end{array}$ & $\begin{array}{r}45 \\
0\end{array}$ & $\begin{array}{r}150 \\
0\end{array}$ & $\begin{array}{r}450 \\
0\end{array}$ & $\begin{array}{l}0 \\
1\end{array}$ & $\begin{array}{l}0 \\
3\end{array}$ & $\begin{array}{r}0 \\
10\end{array}$ & $\begin{array}{r}0 \\
30\end{array}$ & $\begin{array}{r}15 \\
1\end{array}$ & $\begin{array}{r}45 \\
3\end{array}$ & $\begin{array}{r}150 \\
10\end{array}$ & $\begin{array}{r}450 \\
30\end{array}$ & 8,12 \\
\hline $\begin{array}{l}\text { Autumn } \\
96\end{array}$ & $\begin{array}{l}30 \text { Sep-15 Nov } \\
1996\end{array}$ & 46 & $\begin{array}{l}N \\
P\end{array}$ & $\begin{array}{l}0 \\
0\end{array}$ & $\begin{array}{r}15 \\
0\end{array}$ & $\begin{array}{r}45 \\
0\end{array}$ & $\begin{array}{r}150 \\
0\end{array}$ & $\begin{array}{r}450 \\
0\end{array}$ & $\begin{array}{l}0 \\
1\end{array}$ & $\begin{array}{l}0 \\
3\end{array}$ & $\begin{array}{r}0 \\
10\end{array}$ & $\begin{array}{r}0 \\
30\end{array}$ & $\begin{array}{r}15 \\
1\end{array}$ & $\begin{array}{r}45 \\
3\end{array}$ & $\begin{array}{r}150 \\
10\end{array}$ & $\begin{array}{r}450 \\
30\end{array}$ & 9,12 \\
\hline $\begin{array}{l}\text { Early spring } \\
97\end{array}$ & $\begin{array}{l}10 \mathrm{Feb}-7 \mathrm{Apr} \\
1997\end{array}$ & 56 & $\begin{array}{l}N \\
P\end{array}$ & $\begin{array}{l}0 \\
0\end{array}$ & $\begin{array}{r}0 \\
10\end{array}$ & $\begin{array}{r}5 \\
10\end{array}$ & $\begin{array}{l}10 \\
10\end{array}$ & $\begin{array}{l}25 \\
10\end{array}$ & $\begin{array}{l}50 \\
10\end{array}$ & $\begin{array}{r}100 \\
10\end{array}$ & $\begin{array}{r}150 \\
10\end{array}$ & $\begin{array}{r}300 \\
10\end{array}$ & $\begin{array}{r}450 \\
10\end{array}$ & $\begin{array}{r}700 \\
10\end{array}$ & $\begin{array}{r}450 \\
0\end{array}$ & $\begin{array}{r}45 \\
0\end{array}$ & 6 \\
\hline $\begin{array}{l}\text { Late spring } \\
97\end{array}$ & $\begin{array}{l}7 \text { Apr-26 May } \\
1997\end{array}$ & 49 & $\begin{array}{l}\mathrm{N} \\
\mathrm{P}\end{array}$ & $\begin{array}{l}0 \\
0\end{array}$ & $\begin{array}{r}0 \\
10\end{array}$ & $\begin{array}{r}5 \\
10\end{array}$ & $\begin{array}{l}10 \\
10\end{array}$ & $\begin{array}{l}25 \\
10\end{array}$ & $\begin{array}{l}50 \\
10\end{array}$ & $\begin{array}{r}100 \\
10\end{array}$ & $\begin{array}{r}150 \\
10\end{array}$ & $\begin{array}{r}300 \\
10\end{array}$ & $\begin{array}{r}450 \\
10\end{array}$ & $\begin{array}{r}700 \\
10\end{array}$ & $\begin{array}{r}450 \\
0\end{array}$ & $\begin{array}{r}45 \\
0\end{array}$ & 5 \\
\hline
\end{tabular}

Chemical and biological analysis. Particulate carbon and nitrogen were measured with a Fisons $\mathrm{CN}$ analyzer (NA $1500 \mathrm{~N}$ ). Particulate phosphate was determined after first heating the filters to $545^{\circ} \mathrm{C}$ for $12 \mathrm{~h}$, then transferring them into Pyrex test tubes, filling them with $5 \mathrm{ml} \mathrm{H}_{2} \mathrm{O}$ (Suprapur) and $0.1 \mathrm{ml} \mathrm{H}_{2} \mathrm{SO}_{4}$ (4 M) and heating them to $96^{\circ} \mathrm{C}$ in a heating block for $1 \mathrm{~h}$. The liquid was thoroughly whirled and the particles were allowed to settle. The supernatant was used to measure particulate $\mathrm{P}$ as orthophosphate according to Grasshoff et al. (1983). Soluble nutrients of ambient seawater were measured with a Continuous Flow Analyzer using the methods of Grasshoff et al. (1983) to determine phosphate, nitrate, ammonium and silicate. All nutrient values in this text are given in molar units.

Algal cells were counted under an inverted microscope (Leitz DMIRB) at $400 \times$ magnification with standard Utermöhl counting chambers (Hydrobios). Up to 1000 cells were counted per sample in triplicate to minimize unevenly distributed subsamples. The better mixed pelagic samples were counted once $(50 \mathrm{ml})$. Taxonomy follows the nomenclature of Round et al. (1990) and Snoeijs (1993-1996), with additional use of Kuylenstierna (1989-1990), Krammer \& Lange-Bertalot (1986-1991) and Pankow (1990).

To compare the different species, which span several size classes, area integrated biovolume was calculated by fitting nearest geometric models, e.g. cuboid, round or elliptic cylinders, or wedge-shaped 'cymbelloids' (C. D. Dürselen \& H. Hillebrand unpubl.). As a simple measurement of community structure, diversity (information theory index according to Shannon-Weaver; $\left.H^{\prime}\right)$ and evenness ( $H^{\prime} / \mathrm{ln} S$ with $S=$ species number) were calculated (see Valiela 1995 for formula and constraints). For comparison of benthic and pelagic species composition a cluster analysis was performed. Therefore data were transformed to abundance classes (1: $<1 \% ; 2: 1-10 \% ; 3: 10-25 \% ; 4: 25-40 \% ; 5:>40 \%$ of biovolume); Euclidean distances were computed and merged by complete linkage (Statistica 5.0).

\section{RESULTS}

\section{Functioning of the experimental setup}

Flow-rate readjustment was necessary only after several weeks, when the stones were heavily colonized and flow resistance became higher. Treatments with irregular flow ( $>10 \%$ deviation for more than $1 \mathrm{wk}$ ) or with microalgal growth in the tubes (indicated in Tables 1 \& 2) were excluded from the analysis. Repeated nutrient analyses of media in the bottles showed that nutrient concentrations were fairly constant (max. difference from expected concentrations: $6.7 \%)$ throughout several days before the next refilling; bacterial consumption of nutrients in the darkened balloon flasks was therefore negligible.

Although the substrates were suspended in the water column to minimize grazing impact, the attached algae were of true benthic origin and different from plankton communities examined at the same time (Fig. 3).

\section{Taxonomic inventory of microphytobenthic communities}

More than 180 species were identified in benthic and plankton samples during this study, but more than $80 \%$ of the total biovolume of microphytobenthos was contributed by fewer than 20 species throughout the year. Tube-dwelling diatoms (Berkeleya rutilans, Haslea crucigera and Navicula grevillei) were highly dominant in spring, accompanied by the diatoms Melosira nummuloides, Tabularia fasciculata and Prosch- 


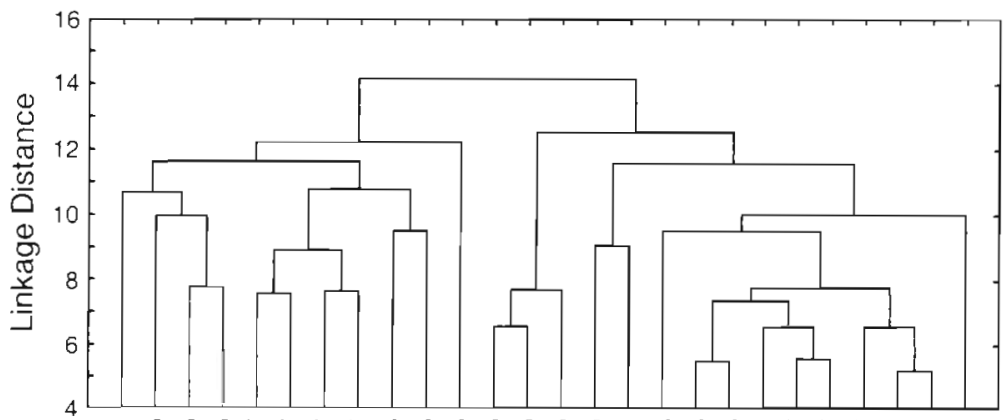

क人⿻ 月\%

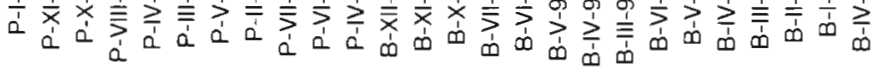

Fig. 3. Dendrogram for cluster analysis calculated with Euclidean distances and amalgamated with complete linkage procedure. In addition to the experiments discussed in the text, monthly samples of unenriched substrates were used as benthic data (marked with B-month-year); pelagic samples are marked P-month-year kinia complanata, and the filamentous chlorophyte Ulothrix flacca. These were succeeded in summer by filamentous phaeophytes (Ectocarpus siliculosus and Pilayella littoralis) and rhodophytes (Ceramium strictum sensu Harvey and Aglaothamnion byssoides) and the large centric diatom Melosira moniliformis. In autumn and winter $M$. moniliformis was common together with Odontella aurita.
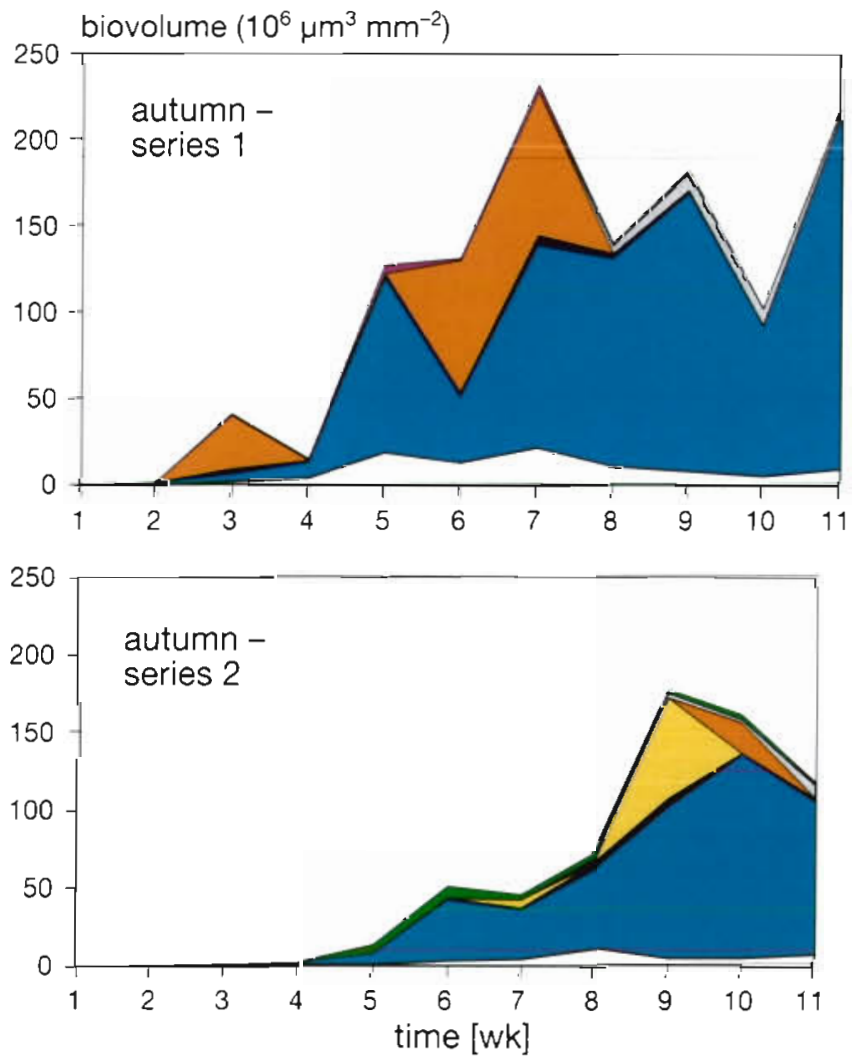

other species Melosira nummuloides Aglaothamnion byssoides Achnanthes longipes
Melosira moniliformis Ceramium strictum Coscinodiscus granii Odontella aurita

\section{Colonization of artificial substrates}

Colonization of artificial substrates was faster at higher temperatures. A plateau of total biovolume was reached after $6 \mathrm{wk}$ during the spring colonization series at temperatures around $10^{\circ} \mathrm{C}$ and after $9 \mathrm{wk}$ in autumn series 2 at temperatures around $5^{\circ} \mathrm{C}$ (Fig. $4 ;$ see also Fig. 7). After only 1 wh unicellular algae,
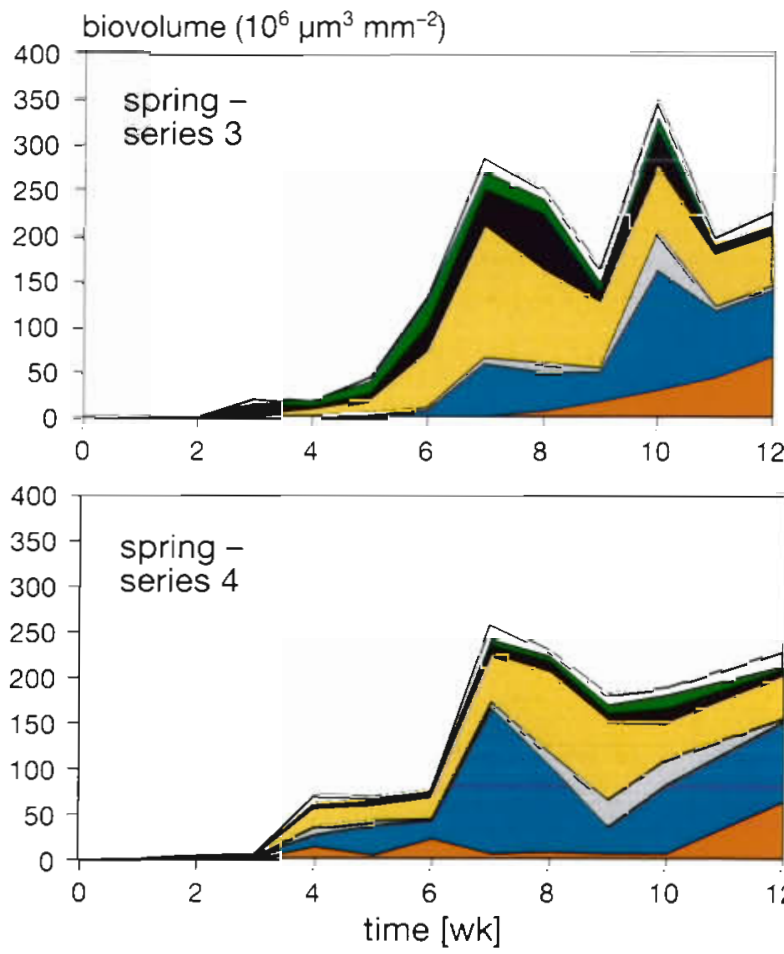

$\square$ Berkeleya rutilans
$\square$ Melosira nummuloides
$\square$ Odontella aurita
$\square$ other species

Haslea crucigera Navicula greville

Tabularia fasciculata

Fig. 4. Colonization of experimental substrata (as biovolume per unit area) in weekly intervals during autumn 1996 and spring 1997 
mostly diatoms, were abundant and the first filamentous algae were recorded after 3 to $4 \mathrm{wk}$. At the beginning of each colonization series, the microphytobenthic community was similar to a random sample of the benthic species suspended in surrounding seawater, but at the end the dominant species were the same in the 2 series of each experiment (Figs, 4 \& 5).

At the level of life forms, erect species became dominant during the first few weeks and remained dominant (Fig, 5). Species numbers increased at the beginning of colonization and remained constant after some weeks. Therefore, no exclusion of species could be determined, but some of the early dominant species decreased during the last weeks of the series (in spring Navicula grevillei and Melosira nummuloides, the latter also in autumn). Diversity and even- autumn series 1

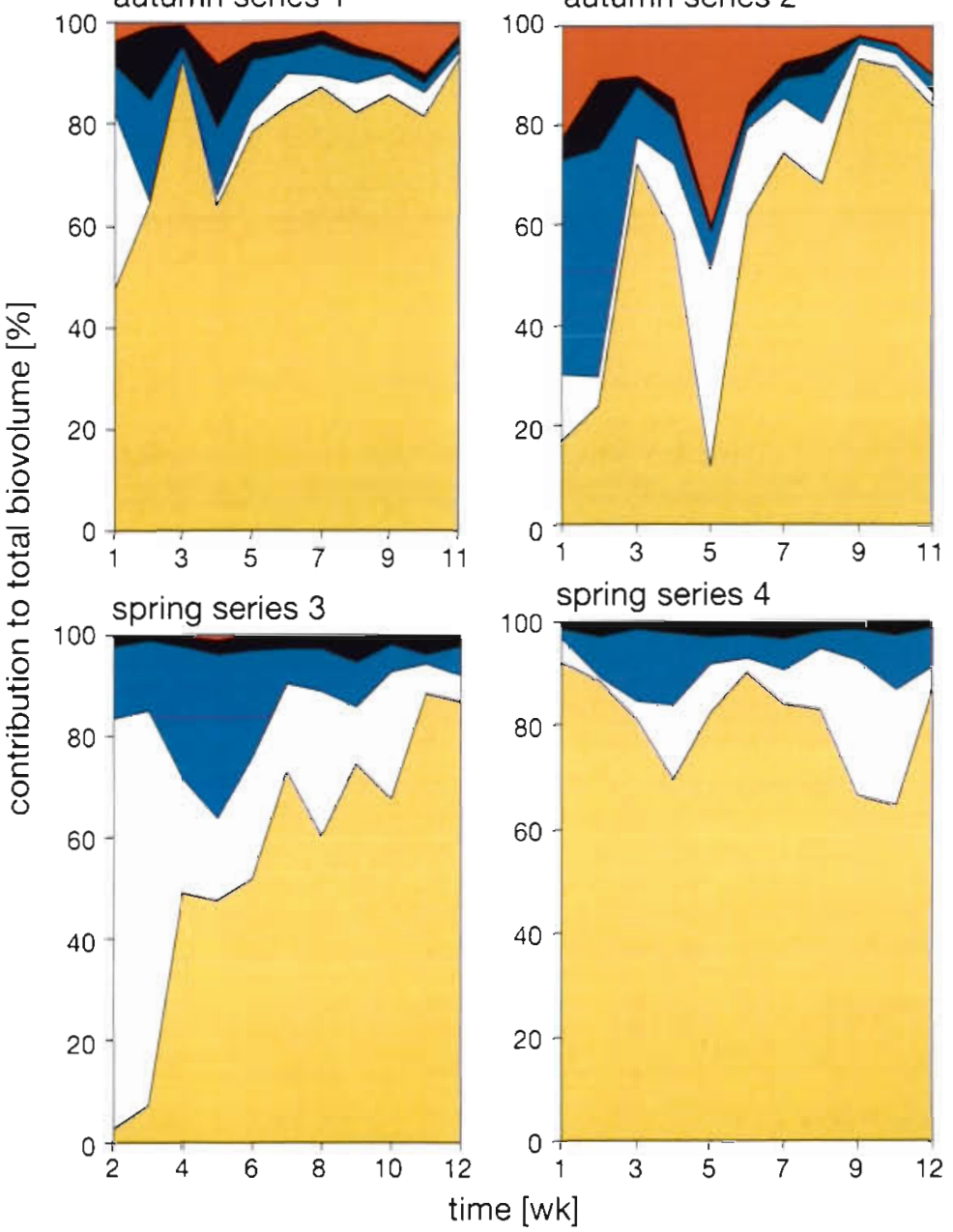

ness decreased during the autumn experiments, as a result of the higher dominance of Melosira moniliformis (Fig. 6). In the spring experiment, diversity and evenness were quite stable throughout the experiment, reflecting the similar contribution of the tube-dwellers

\section{Enrichment experiments}

Total biovolume increased with nutrient enrichment in most of the experiments (Table 3), but the response to nutrient treatments differed seasonally. Increases in total biovolume depended on ambient seawater conditions (Figs. 7 \& 8). In late summer and autumn 1996 as well as in late spring 1997, only substrates supplied with $\mathrm{N}$ had increased biovolume (Table 3, Fig. 8). During these experiments ambient nutrient ratios indicated a surplus of $P$ relative to $N$ $(\mathrm{N}: \mathrm{P}<16$ ) (Fig. 7). In spring 1996, ambient N:P decreased from 50 to 12 (Fig. 7) and a response to treatments receiving $\mathrm{P}$-enrichment only was visible (Fig. 8). In early spring 1997, nutrient enrichment had no conspicuous effect on total biovolume (Table 3).

The dominant taxa showed quite distinct reactions to nutrient treatments (Table 4). Most of the species abundant in summer were stimulated only by increased nitrogen concentrations. These included Ceramium strictum (Fig. 9a) and Melosira moniliformis (Fig. 9b), as well as Tabularia fasciculata (Fig. 9c) and Navicula grevillei (Fig. 9f). $M$. nummuloides increased at low nitrogen enrichment, but was replaced by other species at higher concentrations (150 or $450 \mathrm{\mu mol} \mathrm{l}^{-1}$ ) (Fig. 9d). A similar reaction was shown by Haslea crucigera (Fig. 9g). Berkeleya rutilans occurred during all seasons, but it dominated in spring and showed greatest abundances when both $\mathrm{N}$ and $\mathrm{P}$ were added (Fig. 9e). Proschkinia complanata was the only species highly favoured by $P$ treatments (Fig. 9h)-regardless of whether the N:P ratio of ambient seawater indicated $P$ limitation or not.

Dominant spring species increased their biovolume through nitrogen treatments 5- to 10-fold at maximum, while summer species showed a much higher augmentation, probably because of the lower concentrations of nitrogen in seawater.

Increasing nutrient supply led to decreasing diversity of microphytobenthic com-
Fig. 5. Contribution of different life forms to biovolume during colonization of experimental substrata, experiments in autumn 1996 and spring 1997 

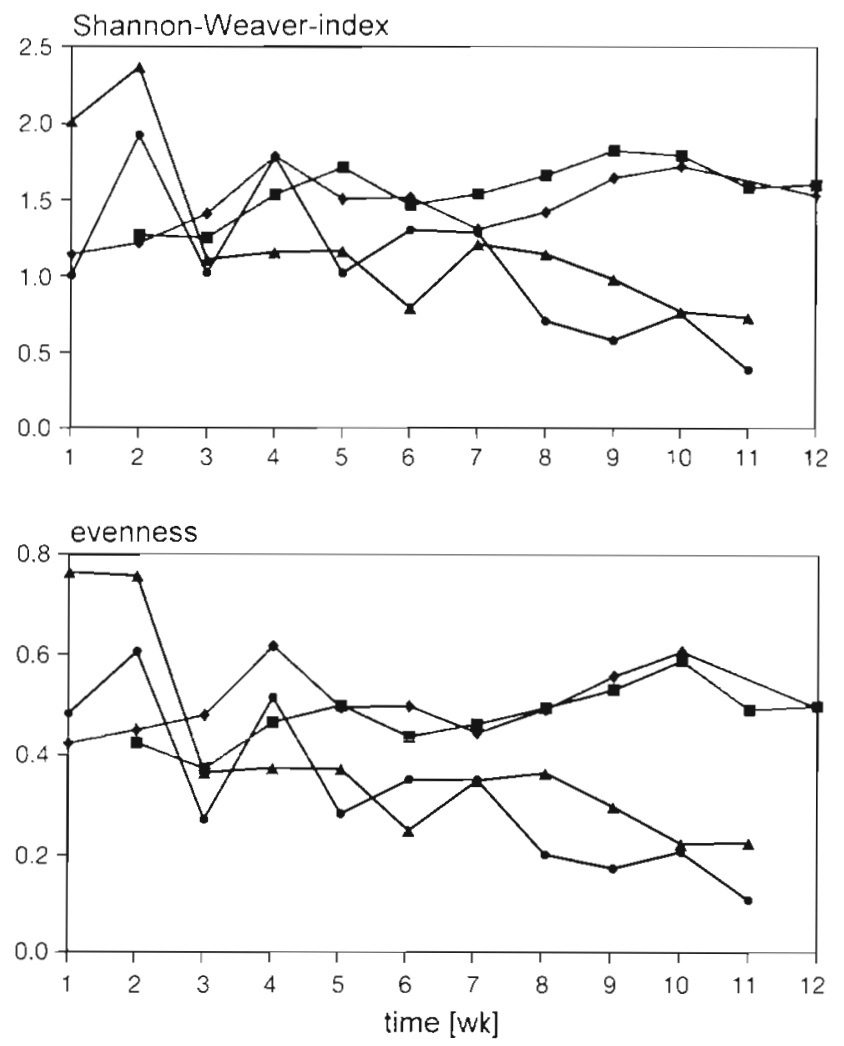

-autumn series 1 -autumn series 2

- spring series $3 \rightarrow$ spring series 4

Fig. 6. Diversity and evenness in weekly intervals during colonization of artificial substrata, experiments from autumn 1996 and spring 1997

\section{DISCUSSION}

Method

The use of artificial substrates has been critizised, because they bias the benthic microflora with regard to attachment ability (Snoeijs 1991). Instead of glass or other smooth surfaces we used kieselguhr stones with a highly structured microtopography, which allowed even filamentous and gelatinous species to attach. These groups are often missing or underrepresented in studies with smooth substrates (Snoeijs 1991). The dominant species in our experiments have been mentioned as common in the Kiel Bight or Western Baltic in several floristic works (Karsten. 1899, Simonsen 1962, Edsbagge 1966, Kuylenstierna 1989-1990, Wendker 1990), and some of them occur in mass blooms. Because of the benthic identity of the community sampled (Fig. 3) and the similarities to species lists from nearby natural sites, porous stones like the ones used are a reliable substrate for ecological research.

By using a gradient of treatment levels rather than replicates of a single treatment level, more information was gained on the quantitative response of benthic microalgae to nutrient enrichment. The continuity of the response was shown by regression analysis (Table 3) and by Spearman rank correlation (Table 4). The colonization experiments showed that biomass had reached a plateau at the time enrichment experiments were harvested. munities, showing a significant decreasing trend with total biovolume (Fig. 10). Splitting the 2 aspects of diversity (species number and evenness), it becomes clear that the enhanced dominance of single or few species was the cause of the decrease of diversity rather than changes in species number.

The C:N ratios of biomass were quite constant throughout the treatments in all experiments, with values higher than the Redfield ratio 6.6 proposed by Goldman et al. (1979) for optimally growing microalgae (Fig. 11). Cellular $\mathrm{N}: \mathrm{P}$ ratios were lower than 15 (except in some treatments in the early spring experiment), but showed a positive correlation ( $p<0.0001)$ to $N: P$ ratios of the supplied media (Fig. 11). This is still significant $(p<0.05)$ if the outlier treatment is deleted.
Table 3. Linear regression of $\log _{10^{-}}$transformed biovolume dependent on $\log _{10^{-}}$ transformed nutrient concentrations. The log-transformation is substantiated by the non-linear increase of nutrient concentrations between treatments. The table lists the experiments, the enriched nutrient and the results of the linear regression (slope, regression coefficient $r^{2}$ and significance level, i.e. $p<0.05$; $\cdots p<0.001)$

\begin{tabular}{|lcccc|}
\hline Experiment & Enrichment & Slope & \multicolumn{1}{c|}{$\mathrm{r}^{2}$} & Significance \\
\hline Spring 1996 & $\mathrm{N}$ & 0.188 & 0.6099 & 0.219 \\
& $\mathrm{P}$ & 0.243 & 0.6349 & 0.1065 \\
& $\mathrm{~N}+\mathrm{P}(15: 1)$ & 0.331 & 0.7674 & 0.0514 \\
Summer 1996 & $\mathrm{N}$ & 0.609 & 0.8553 & $0.0245^{\circ}$ \\
& $\mathrm{P}$ & 0.422 & 0.5648 & 0.2485 \\
& $\mathrm{~N}+\mathrm{P}(15: 1)$ & 0.691 & 0.9773 & 0.0114 \\
Autumn 1996 & $\mathrm{N}$ & 0.564 & 0.7993 & 0.0408 \\
& $\mathrm{P}$ & -0.047 & 0.023 & 0.8484 \\
& $\mathrm{~N}+\mathrm{P}(15: 1)$ & 0.449 & 0.9272 & $0.0371^{\circ}$ \\
Early spring 1997 & $\mathrm{N}$ & -0.035 & 0.2317 & 0.5187 \\
& $\mathrm{~N}(+10 \mu \mathrm{MP})$ & 0.02 & 0.0339 & 0.6352 \\
Late spring 1997 & $\mathrm{N}$ & 0.218 & 0.995 & $0.0448^{\circ}$ \\
& $\mathrm{N}(+10 \mu \mathrm{M})$ & 0.189 & 0.9107 & 0.0001 \\
& & & & \\
\hline
\end{tabular}


The advantages of the present experimental setup were the continuous supply of nutrients to the benthic community and the constancy of the nutrient supply rates, in addition to the fact that the setup was simple and inexpensive. However, there are disadvantages: each treatment can only be harvested once and the algal community is exposed to ambient nutrient concentrations as well as to media concentrations, so the final nutrient regime is dependent on both. Nevertheless, the constant supply rate makes this experimental design superior to those with diffusing substrates with exponentially declining rates, in which the nutrient regime constantly changes during the experimental period (see Flothmann \& Werner 1992). Herbivores (mainly nematodes and copepods) were present on stones in low abundances and were not systematically correlated to algal biovolume or nutrient treatment (insignificant Spearman rank correlation). Therefore they are not considered a possible cause for the changed community composition in the treatments.

\section{Colonization process}

The colonization series were marked by an increased dominance of erect species with time (Fig. 5). Hudon \& Bourget (1981) and others describe a shift in dominance from adnate to erect species during colonization of free substrates. This upper story is thought to determine the community structure and response of benthic communities to nutrient treatment (Paul \& Duthie 1989). The next stage is established through colonization of erect species by epiphytes, resulting in a high level of structural complexity. The stable diversity in the spring colonization series and the constant species numbers do not correspond to previous findings. Highest diversity is usually associated with mid-successional stages (Valiela 1995 and references therein), with low diversity at early succesional stages due to few pioneering species and at later stages due to species competitive exclusion. In the present study the previously described structural variability and the nearby presence of a source-pool of species for new-or re-colonization may have reduced species exclusion.

\section{Enrichment experiments}

The observed biovolume increase due to nutrient enrichment showed nutrient limitation in the unen-

\section{duration of experiments}
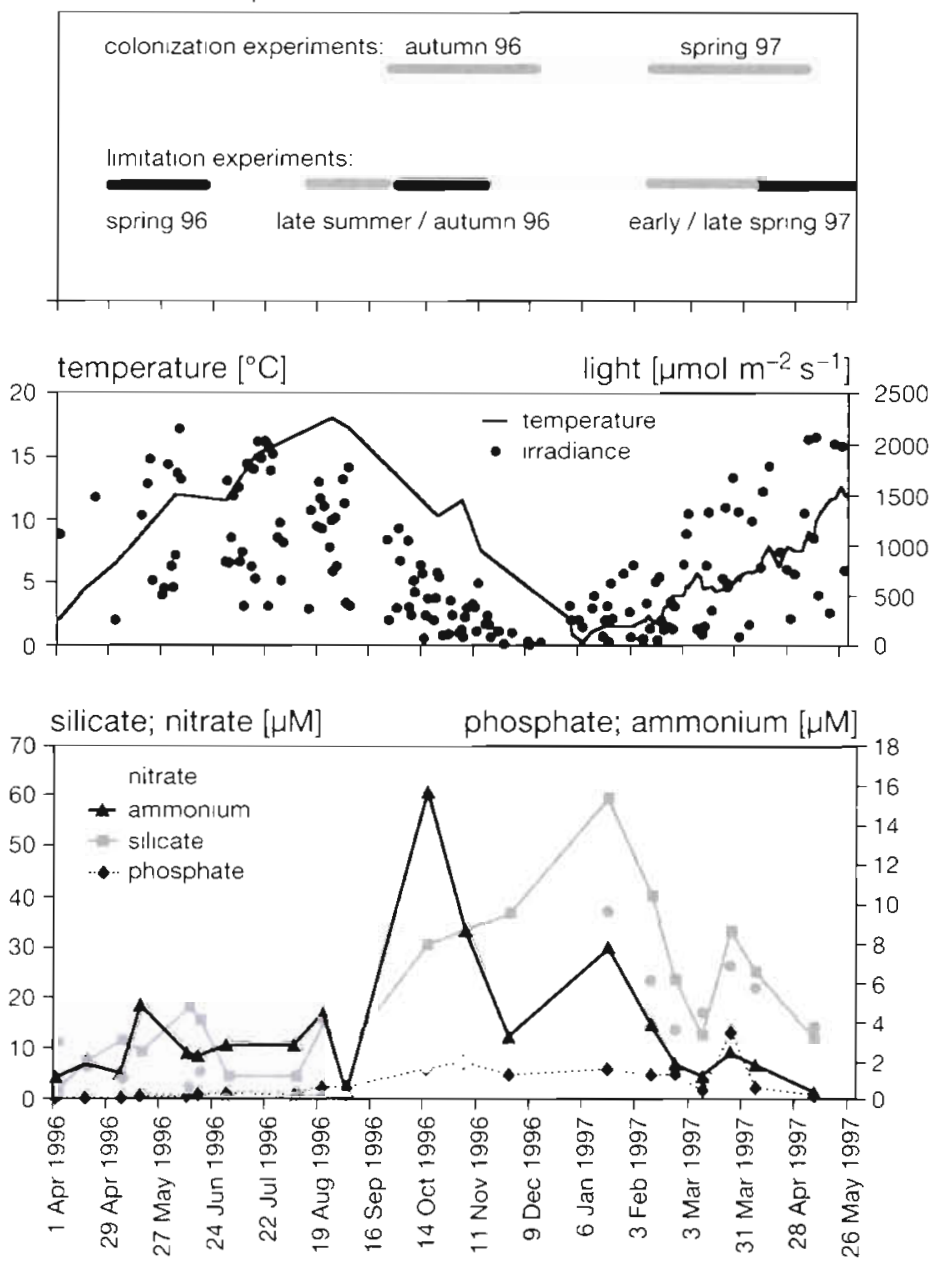

Fig. 7. Duration of experiments (indicated by horizontal bars in the top panel) in comparison to abiotic conditions at the pier of the Institute of Marine Science, Kiel. Middle panel: water surface temperature and irradiance at 12:00 h MEST (Middle European Summer

Time). Lower panel: nutrient concentrations of ambient seawater

riched treatments. During late spring, summer and autumn, nitrogen was limiting (Table 3). In spring 1996 a colimitation of nitrogen and phosphate can be deduced from the simultaneous biovolume increase after nitrogen or phosphate enrichment. Nutrient limitation seemed to be strongest in our summer and autumn experiment with the highest biomass stimulation (i.e. highest slopes in Table 3) compared to the control. In early spring the nutrient treatments failed to produce higher biovolume yields than the control (Table 3). We assume that low light conditions (irradiance and daylengthj and low temperature in contrast to high ambient seawater nutrients (Fig. 7) precluded nutrient limitation during winter and early spring (Cadée \& Hegeman 1974, Admiraal \& Peletier 1980, for freshwater phytoplankton see Sterner 1994). The changing importance of nutrient conditions during 

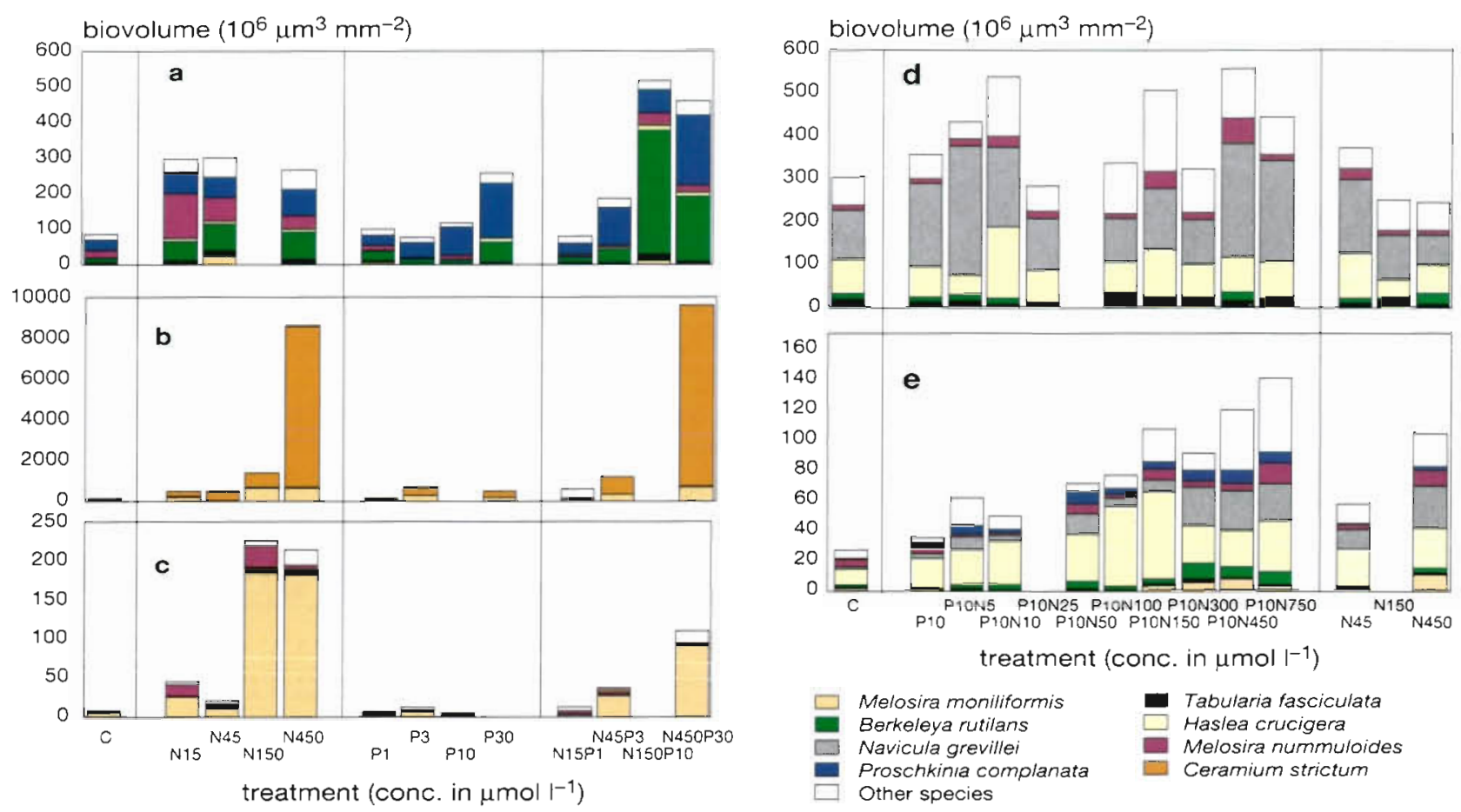

Fig. 8. Total biovolume at the end of enrichment experiments and contribution of dominant species. Experiments from (a) spring 1996, (b) late summer 1996, (c) autumn 1996, (d) early spring 1997 and (e) late spring 1997. Nutrient concentrations are given in $\mu \mathrm{mol} \mathrm{l}^{-2}$ (e.g. N45P3 means $45 \mu \mathrm{mol} \mathrm{l}^{-1} \mathrm{~N}$ and $3 \mu \mathrm{mol} \mathrm{l}^{-1} \mathrm{P}$ )

seasonal succession is well understood for freshwater phytoplankton (Sommer et al. 1986) and further research should be done to reveal the influence of nutrients, grazing, and abiotic conditions on microphytobenthos throughout the year.

Epilithic microalgae are dependent only on nutrients from the water column and recirculation within the biofilm, but sediment-inhabiting microalgae also receive pore-water nutrients. Therefore, a direct application of our results to microphytobenthos on sediments is not possible. However, together with results from marine and freshwater habitats revealing biomass stimulation due to nutrient enrichment (Fairchild et al. 1985, Sundbäck \& Snoeijs 1991, Rosemond et al. 1993, Coleman \& Burkholder 1994, Nilsson 1995), the conclusion has to be drawn that nutrient limitation is often present in microphytobenthic communities of different substrate specification.

The internal N:P ratios of the biomass ranged from 1.7 to 64 and increased conspicuously if media with an increased N:P ratio was supplied (Fig. 11). Similar results were obtained by Myklestad (1977) in experiments with 2 diatoms. From this increase we can deduce that internal nitrogen pools were unsaturated in unenriched treatments (Droop 1983), supporting the observed biomass increase in the enriched treatments.

Table 4. Correlation between relative biovolume (control $=100 \%$ ) of dominant species and nutrient treatment. Spearman rank correlation was calculated for $N, P$ and $N+P$ treatments using the experiments from 1996, and for $N+$ constant $P$ treatments using the experiments from 1997. If the abundance of species was very low ( $<5 \%$ of total biovolume in all treatments), single experiments were used as indicated. The table lists species and coefficients for the respective treatment (significance: " $p<0.05$, $\cdots p<0.01, \cdots p<0.001, \cdots p<0.0001$, ns: not significant, - : not calculated)

\begin{tabular}{|c|c|c|c|c|c|}
\hline Species & $N$ & $P$ & NP $(15: 1)$ & $N+$ const. $P$ & \\
\hline Berkeleya rutilans & $0.709^{\circ}$ & ns & $0.746^{\circ}$ & $0.767^{\circ}$ & \\
\hline Ceramium strictum & $1.0 \cdots$ & ns & $1.0^{\cdots} \cdot$ & - & Only late summer 1996 \\
\hline Haslea crucigera & ns & ns & ns & ns & \\
\hline Melosira moniliformis & $0.884^{\cdots}$ & ns & $0.78^{\circ}$ & - & Only late summer \& autumn 1996 \\
\hline M. nummuloides & ns & ns & ns & ns & \\
\hline Navicula grevillei & - & - & - & $0.767^{\circ}$ & \\
\hline Proschkinia complanata & ns & $0.724 \cdots$ & $0.809 \cdots$ & ns & \\
\hline Tabularia fasciculata & $0.801 \cdots$ & ns & $0.571^{\circ}$ & $0.731^{\circ}$ & \\
\hline
\end{tabular}



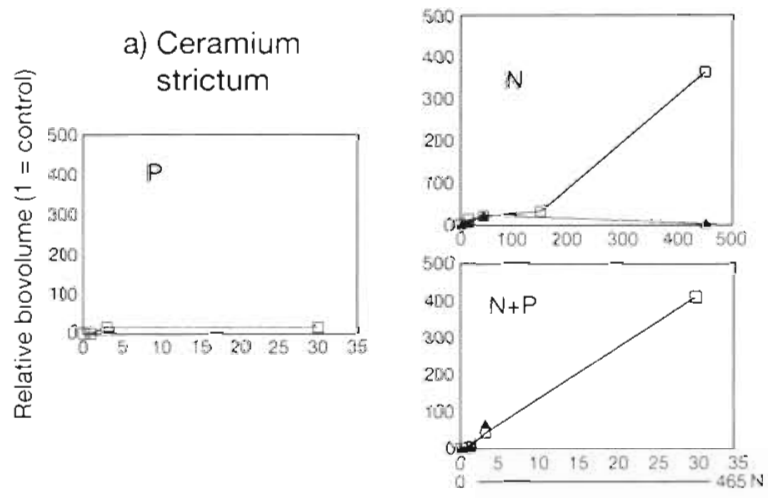

b) Melosira moniliformis
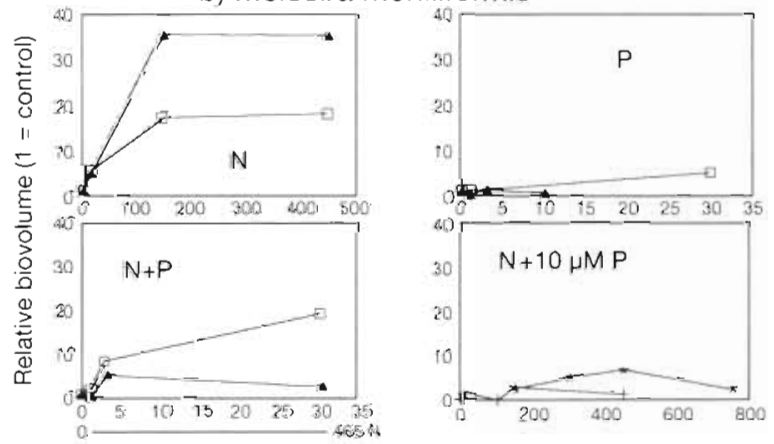

c) Tabularia fasciculata
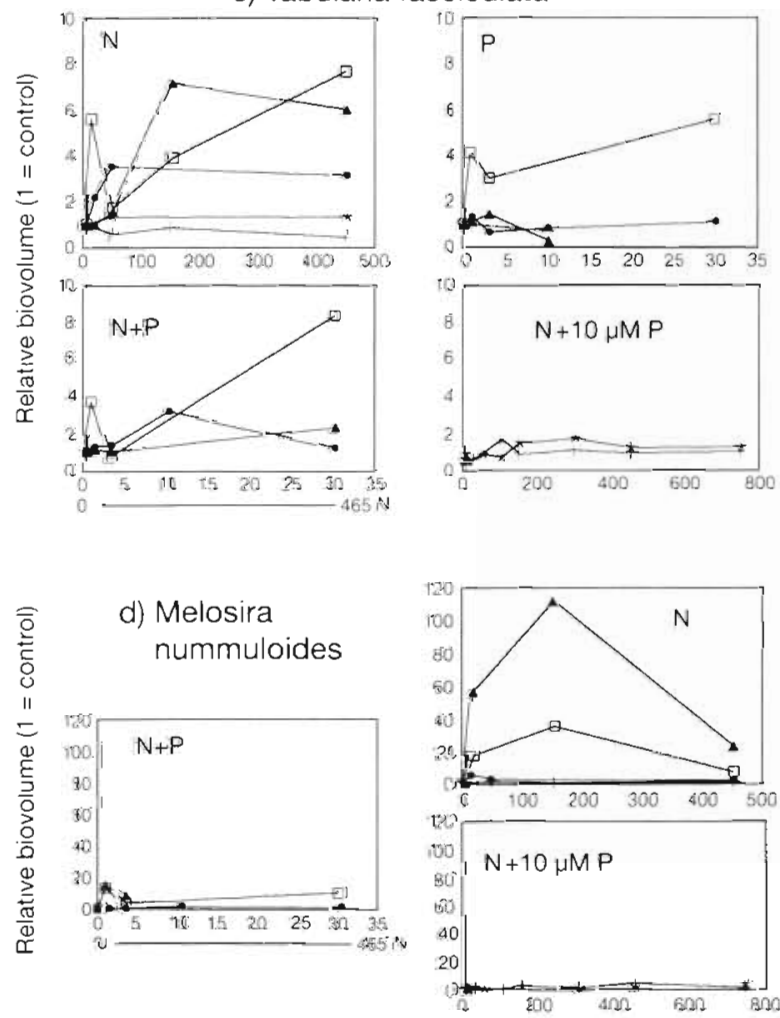

e) Berkeleya rutilans
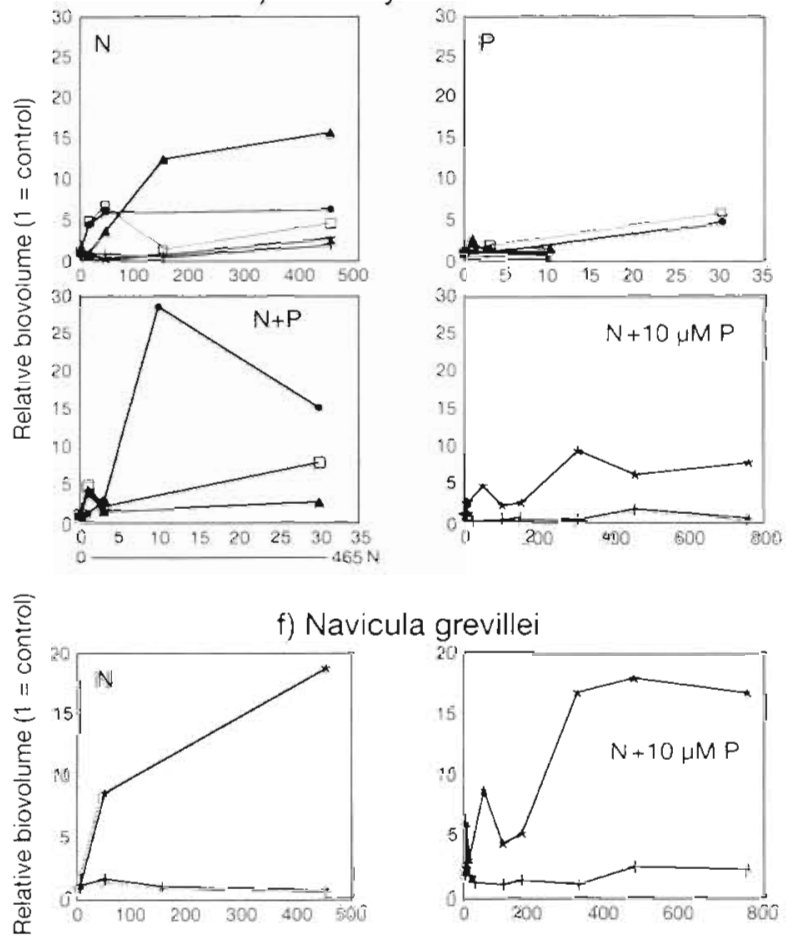

g) Haslea crucigera
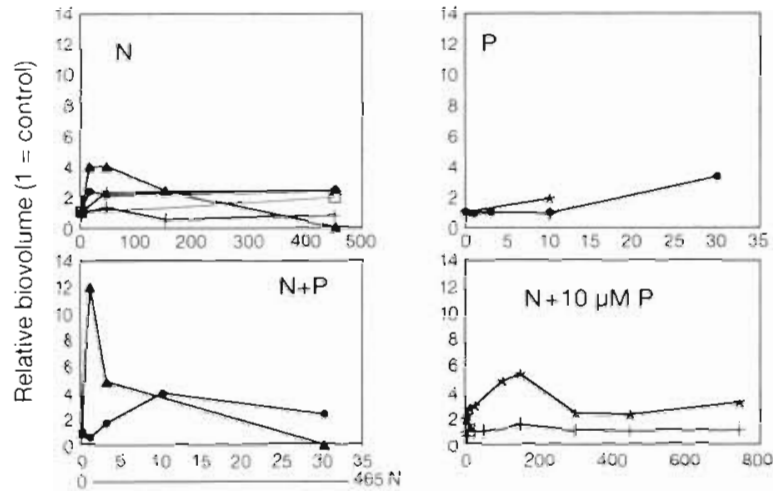

h) Proschkinia complanata

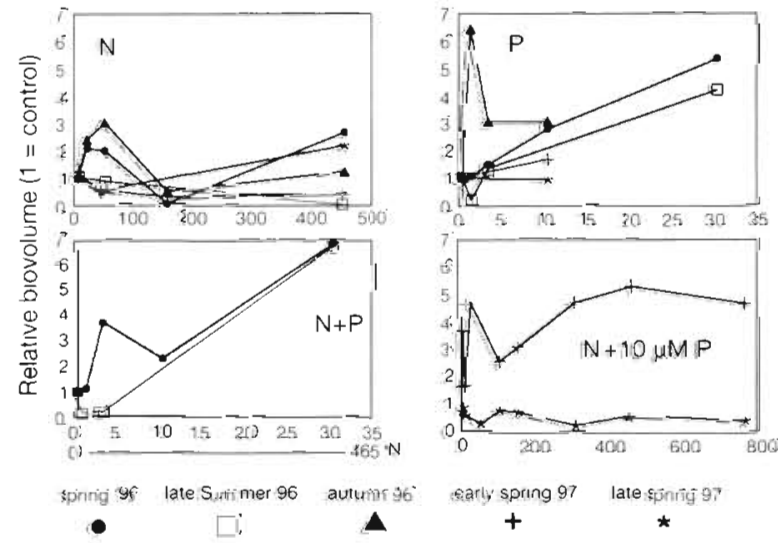

Fig. 9. Development of dominant species with nutrient treatments during different experiments. Biovolume is given in relation to control; for most species diagrams are shown for treatments enriched with $\mathrm{N}$ alone, $\mathrm{P}$ alone, $\mathrm{N}+\mathrm{P}$ in a molar $15: 1$ ratio and $\mathrm{N}+\mathrm{P}$ with a constant $P$ concentration $\left(10 \mu \mathrm{mol}^{-1}\right)$ and increasing $N$. All concentrations are in $\mu \mathrm{mol} \mathrm{I}^{-1}$; in the $\mathrm{N}+\mathrm{P}$ enrichments the $\mathrm{N}$ concentrations are given in the second $x$-axis ranging from 0 to $465 \mu \mathrm{mol}^{-1}$ Diagrams were omitted when the respective species 


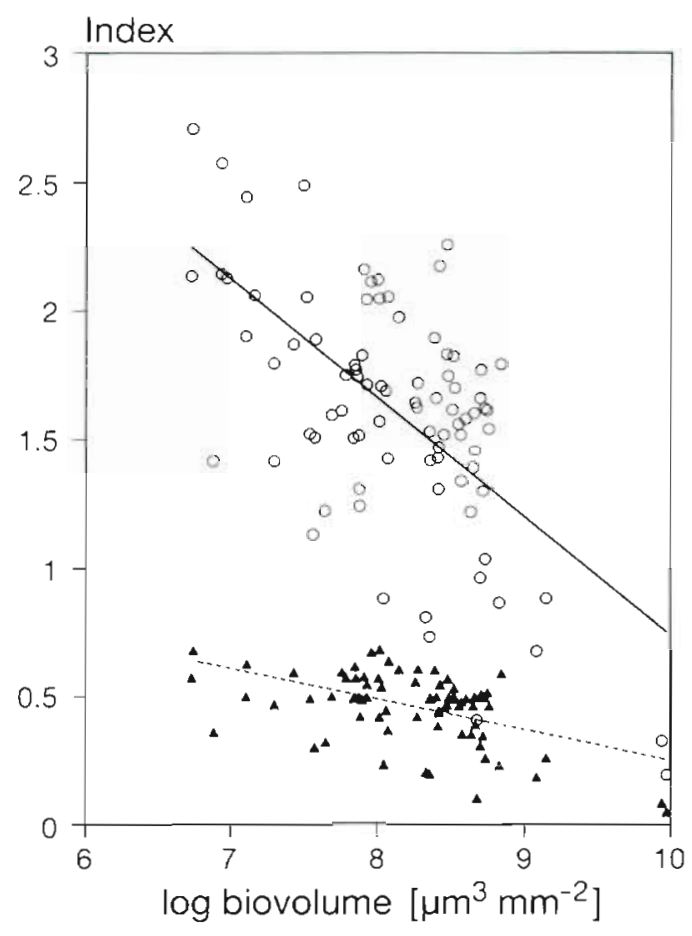

Fig. 10. Diversity $H^{\prime}(0)$ and evenness $E(\boldsymbol{\Lambda})$ of final compositions of the different treatments in all experiments correlated to log-transformed final biovolume $\left(B V_{\text {lag }}\right)$. The expressions of the linear regressions are $H^{\prime}=-0.469 B V_{\log }+5.372\left(r^{2} \cdot 0.389\right.$, $\mathrm{p}<0.001)$ and $E=-0.121 B V_{\log }+1.467\left(\mathrm{r}^{2}: 0.266 ; \mathrm{p}<0.001\right)$

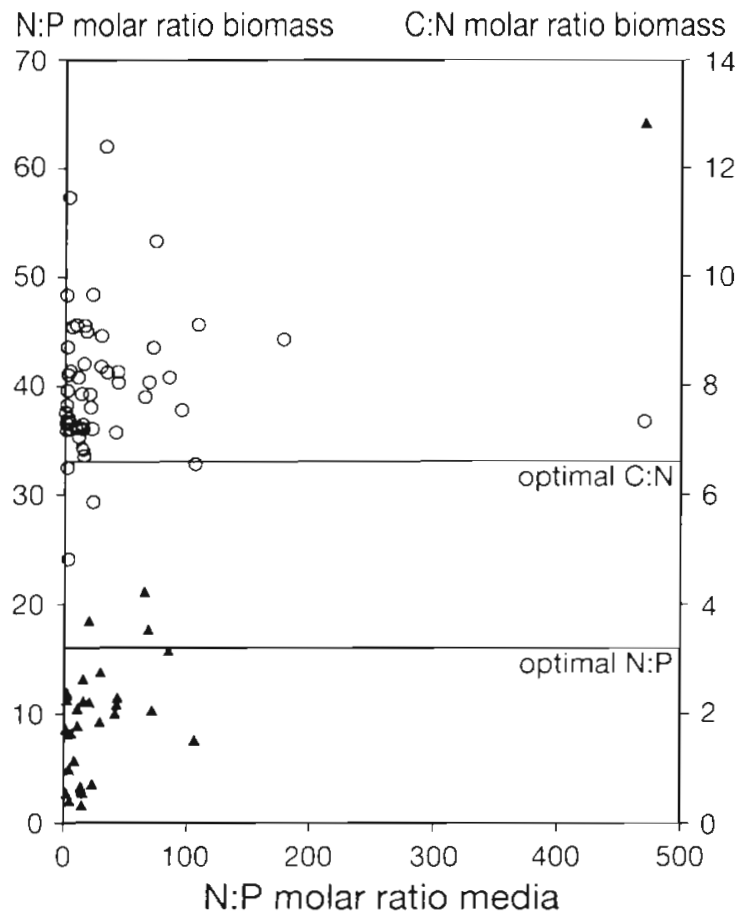

Fig. 11. N:P and C:N molar ratios of biomass depending on media N:P ratio of treatments. (4) N:P ratios, (0) C:N ratios; horizontal lines indicate Redfield ratios for $\mathrm{N}: \mathrm{P}$ and $\mathrm{C}: \mathrm{N}$ respectively
The dependency of cellular stoichiometry on nutrient limitation is not well known for benthic marine microalgae. Assuming a basic physiological analogy to phytoplankton, the C:N:P ratio 106:16:1 (Redfield ratio) can be employed as an estimate for algal biomass under optimal growth conditions (see e.g. Goldman \& McCarthy 1978, Goldman et al. 1979). C:N ratios are not strongly affected by light and temperature conditions but are strongly affected by nutrient supply (cf. Flynn 1990). N limitation leads to a deviation of the cellular $\mathrm{C}: \mathrm{N}$ ratios from the Redfield ratio due to the production of organic matter rich in carbon and low in nitrogen (Conover 1975, Harrison et al. 1977) and depletion of internal $N$ pools (Dortch 1982, Dortch et al. 1984). The cellular biomass composition in our experiments supported the conclusion that the microflora was nitrogen limited in most cases. The $\mathrm{C}: \mathrm{N}$ ratio was seldom lower than 6.6 and was as high as 13 . The N:P ratio was less than 16 and the C:P ratio was less than 106, indicating a $\mathrm{P}$ surplus. This conclusion can still be sustained if the comparison is based on recent in situ data of slightly higher optimal C:N:P ratios in freshwater microphytobenthos (158:18:1) (Kahlert in press).

Competition can be expected to play an important role as a consequence of the nutrient-limited situation which exists during most of the year. No attempt was made to calculate the exact nutrient ratios around the stone because supplied media mingled with surrounding seawater concentrations. Therefore, the resourceratio hypothesis cannot be applied (Tilman 1982). But the nutrient supply of $\mathrm{N}$ or $\mathrm{P}$ from the stones alone clearly shifted the N:P ratio experienced by the algae (see Fig. 11), and a comparison to the results from other experiments is therefore possible. In our experiments, diatoms were dominant in all experiments but one. In contrast, other studies have reported a change in dominance of higher taxa due to nutrient treatments. Cyanobacteria have become more important when only phosphate (lowering of $\mathrm{N}: \mathrm{P}$ ) was added because of their ability to fix $\mathrm{N}_{2}$ (Pinckney et al. 1995). In laboratory experiments benthic algae grown with different nutrient ratios showed responses similar to those observed for higher taxa of phytoplankton. Diatoms dominated at high Si:N and Si:P ratios. At low silicate concentrations, chlorophytes dominated at high N:P and cyanobacteria at low N:P (Sommer 1996, see also above). In the experiments by Nilsson (1995) diatoms were only replaced at high $\mathrm{N}+\mathrm{P}$ addition without extra silicate and they remained dominant when $\mathrm{Si}+\mathrm{N}+\mathrm{P}$ were added. On the other hand, Sundbäck \& Snoeijs (1991) found no dominance shift during $N+P$ addition. They attributed this lack of response to their use of sediment which acted as a silicate-pool. Similarly, in our experiments the material of the stones (infusory earth) may have been a secondary Si-source. 
While dominance of higher taxa was not changed by nutrient enrichment in our experiments, distinct shifts in dominance at the level of species were visible. The most abundant species differed clearly in their response to the supplied nutrients (Table 4), leading to altered community composition (Fig. 8). Previously, a lack of change in species assemblage (Pinckney et al. 1995) as well as slight changes (increase of Nitzschia and Amphora species; Sundbäck \& Snoeijs 1991) have been observed. Rosemond et al. (1993) investigated simultaneous bottom-up and top-down control in a stream and showed an effect of nutrients on biomass, but the species composition was more strongly controlled by grazing. Distinct dominance changes within higher taxa were described by Sommer (1996). When he used species that were also abundant in our in situ experiments, the responses to nutrient treatments were similar to those of the present study. Melosira nummuloides was favoured in his culture experiments by high silicate and a N:P ratio around 15. In situ it was favoured at low nitrogen enrichments and similar N:P ratios. Berkeleya rutilans (= Amphipleura rutilans in Sommer 1996) was most important at high N:P ratios in the laboratory (N:P 145:122:1) as well as in situ (Table 4). The higher nitrogen demand of this species may be due to the unique protein content of its tube walls (Daniel et al. 1987). Tabularia fasciculata showed a positive response to nitrogen enrichment in the culture experiments and in silu.

The decrease in diversity with nutrient enrichment and increased biovolume was not due to species loss because species number was quite stable within the experiments. Instead, decreasing evenness resulted from the importance of enhanced dominance of a single or a few species (cf. Fairchild et al. 1985, Carrick et al. 1988). A decrease in diversity with nutrient enrichment was observed in several other studies (Sullivan 1976, Carrick et al. 1988), whereas others found no or insignificant changes in diversity (Sullivan 1981, Sundbäck \& Snoeijs 1991).

In conclusion, a nutrient limitation of the growth of epilithic microflora in the Kiel Fjord occurs, and is of seasonally varying importance. Nitrogen was the main limiting nutrient for most species, except for diatoms, which may have been silica deficient in summer on natural substrates. Nutrient-enriched treatments led to altered or enhanced dominance of a single or a few species, from which we derive that competition may act as one major factor determining microphytobenthic species composition.

Acknowledgements. We are indebted to Cordula Stielau, Thomas Hansen and Petra Deegen for practical help. Bob Sterner, Herwig Stibor, Anja Göbel and 4 anonymous reviewers provided useful comments on the manuscript. The work was funded by the Deutsche Forschungsgemeinschaft (DFG) grant no. DFG-So-145/15-1

\section{LITERATURE CITED}

Admiraal W (1984) The ecology of estuarine sedimentinhabiting diatoms. Prog Phycol Res 3:269-322

Admiraal W, Peletier H (1980) Influence of seasonal variations of tempcrature and light on the growth rate of cultures and natural populations of intertidal diatoms. Mar Ecol Prog Ser 2:35-43

Cadée GC (1980) Reappraisal of the production and import of organic carbon in the western Wadden Sea. Neth J Sea Res 14:305-322

Cadée GC, Hegeman J (1974) Primary production of the benthic microflora living on tidal flats in the Dutch Wadden Sea. Neth J Sea Res 8:260-291

Carrick HJ, Lowe RL, Rotenberry JT (1988) Guilds of benthic algae along nutrient gradients: relationships to algal community diversity. J North Am Benthol Soc 7:117-128

Coleman VL, Burkholder JM (1994) Community structure and productivity of epiphytic microalgae on eelgrass (Zostera marina L.) under water column nitrate enrichment. J Exp Mar Biol Ecol 179:29-48

Conover SAM (1975) Partitioning of nitrogen and carbon in cultures of the marine diatom Thalassiosira fluviatilis supplied with nitrate, ammonium or urea. Mar Biol 32: 231-246

Daehnick AE, Sullivan MJ, Moncrelff CA (1992) Primary production of the sand microflora in seagrass beds of Mississippi Sound. Bot Mar 35:131-139

Daniel GF, Chamberlain AHL, Jones EBG (1987) Cytochemical and electron microscopical observations on the adhesive materials of marine fouling diatoms. Br Phycol J 22: $101-118$

Dortch Q (1982) Effect of growth conditions on accumulation of internal nitrate, ammonium, amino acids, and protein in three marne diatoms. J Exp Mar Biol Ecol 61:243-264

Dortch Q. Clayton JR, Thoresen SS, Ahmed Sl (1984) Species differences in accumulation of nitrogen pools in phytoplankton. Mar Biol 81:237-250

Droop MR (1983) 25 years of algal growth kinetics. Bot Mar 26:99-112

Edsbagge $H$ (1966) Zur Ökologie der marinen angehefteten Diatomeen. Bot Gothob Acta Univ Gothob VI:1-155

Fairchild GW, Lowe RL, Richardson WB (1985) Algal periphyton growth on nutrient diffusing substrates: an in situ bioassay. Ecology 66:465-472

Flothmann S, Werner I (1992) Experimental eutrophication on an intertidal sandflat: effects on microphytobenthos, meioand macrofauna. In: Colombo G, Ferrari I, Ceccherelli VU, Rossi R (eds) Marine eutrophication and population dynamics. Proceedings from the 25th EMBS, Olsen \& Olsen, Fredensborg, p 93-100

Flynn KJ (1990) The determination of nitrogen status in microalgae. Mar Ecol Prog Ser 61:297-307

Goldman JC, McCarthy JJ (1978) Steady state growth and ammonium uptake of a fast-growing marine diatom. Limnol Oceanogr 23:695-703

Goldman JC, McCarthy JJ, Peavey DG (1979) Growth rate influence on the chemical composition of phytoplankton in oceanic waters. Nature 279:210-215

Grasshoff K, Ehrhardt M, Kremling K (1983) Methods of seawater analysis, 2nd edn. Verlag Chemie, Weinheim

Harrison PJ, Conway HL, Holmes RW, Davis CO (1977) Marine diatoms grown in chemostats under silicate or ammonium limitation. IIl. Cellular chemical composition and morphology of Chaetoceros debilis, Skeletonema costatum and Thalassiosira gravida. Mar Biol 43:19-31

Hudon C, Bourget E (1981) Initial colonization of artificial 
substrate: community development and structure studied by scanning electron microscopy. Can J Fish Aquat Sci 38:1371-1384

Kahlert $M$ (in press) C:N:P ratios of freshwater benthic algae. Arch Hydrobiol Suppl

Karsten G (1899) Die Diatomeen der Kieler Bucht. Wiss Meeresunters K Komm Kiel 4:19-205

Krammer K, Lange-Bertalot H (1986-1991) Süßwasserflora von Mitteleuropa, Band 2: Bacillariophyceae/1 Teil Naviculaceae. 2. Teil Bacillariaceae, Epithemiaceae, Surirellaceae. 3. Teil Centrales, Fragiliariaceae, Eunotiaceae 4. Teil Achnanthaceae, krit. Ergänzungen zu Navicula (Lineolatae) und Gomphonema. Gustav Fischer Verlag, Stuttgart

Kuylenstierna M (1989-1990) Benthic algal vegetation in the Nordre Älv estuary, Swedish West Coast, Vol 1 \& 2. Dissertation, University Göteborg

Myklestad S (1977) Productions of carbohydrates by marine planktonic diatoms. II: Influence of the N/P ratio in the growth medium on the assimilation ratio, growth rate, and production of extracellular carbohydrates by Chaetoceros affinis var willei (Gran) Hustedt and Skeletonema costatum (Grev.) Cleve. J Exp Mar Biol Ecol 29:161-179

Nilsson C (1.995) Microbenthic communities with emphasis on algal-nutrient relations. Dissertation, University Göteborg

Pankow H (1990) Ostsee-Algenflora. Gustav Fischer Verlag, Jena

Paul BJ, Duthie HC (1989) Nutrient cycling in the epilithon of running waters. Can J Bot 67:2302-2309

Pinckney J, Paerl HW, Fitzpatrick M (1995) Impacts of seasonality and nutrients on microbial mat community structure and function. Mar Ecol Prog Ser 123:207-216

Pringle CM (1987) Effects of water and substratum nutrient supplies on lotic periphyton growth: an integrated bioassay. Can J Fish Aquat Sci 44:619-629

Pringle CM (1990) Nutrient spatial heterogeneity: effects on community structure, physiognomy, and diversity of stream algae. Ecology 71:905-920

Pringle CM, Bowers JA (1984) An in situ substratum fertilization technique: diatom colonialization on nutrientenriched, sand-substrata. Can J Fish Aquat Sci 41: $1247-1251$

Rosemond AD, Mulholland PJ, Elwood JW (1993) Top-down and bottom-up control of stream periphyton: effects of nutrients and herbivores. Ecology 74:1264-1280

Round FE, Crawford RM, Mann DG (1990) The diatoms-

Editorial responsibility: Otto Kinne (Editor),

Oldendorf/Luhe, Germany biology and morphology of the genera. Cambridge University Press, Cambridge

Simonsen R (1962) Untersuchungen zur Systematı und Ökologie der Bodendiatomeen der westlichen Ostsee. Int Rev Ges Hydrobiol Syst Beih 1:1-144

Snoeijs P (1991) Monitoring pollution effects by diatom community composition. A comparison of sampling methods. Arch Hydrobiol 121:497-510

Snoeijs P, Vilbaste C, Potapova M, Kasperoviciene J (eds) (1993-1996) Intercalibration and distribution of diatom species in the Baltic Sea, Vol 1-4. Baltic Mar Biologists Publ 16a-d. Opulus Press, Uppsala

Sommer U (1985) Comparison between steady state and nonsteady state competition: experiments with natural phytoplankton. Limnol Oceanogr 30:335-346

Sommer U (1994) Are marine diatoms favoured by high Si:N ratios? Mar Ecol Prog Ser 115:309-315

Sommer U (1996) Nutrient competition experiments with periphyton from the Baltic Sea. Mar Ecol Prog Ser 140: 161-167

Sommer U, Gliwicz ZM, Lampert W, Duncan A (1986) The PEG-model of seasonal succession of planktonic events in fresh waters. Arch Hydrobiol 106:433-471

Sterner RW (1994) Seasonal and spatial patterns in macroand micronutrient limitation in Joe Pool Lake, Texas Limnol Oceanogr 39:535-550

Sullivan MJ (1976) Long term effects of manipulating light intensity and nutrient enrichment on the structure of a salt marsh diatom community. J Phycol 12:205-210

Sullivan MJ (1981) Effects of canopy removal and nitrogen enrichment on a Distichlis spicata edaphic diatom complex. Estuar Coast Shelf Sci 13:119-129

Sundbäck K, Snoeijs P (1991) Effects of nutrient enrichment on microalgal community composition in a coastal shallow-water sediment system: an experimental study. Bot Mar 34:341-358

Tilman D (1977) Resource competition between planktonic algae: an experimental and theoretical approach. Ecology $58: 338-348$

Tilman D (1982) Resource competition and community structure. Princeton University Press, Princeton

Valiela I (1995) Marine ecological processes, 2nd edn. Springer Verlag, Berlin

Wendker S (1990) Untersuchungen zur subfossilen und rezenten Diatomeenflora des Schleiästuars (Ostsee). Bibl Diatomol 20. J. Cramer Verlag, Braunschweig

Submitted: July 21, 1997, Accepted: October 10, 1997

Proofs received from author(s): November 26, 1997 